\title{
Predicting the environmental thresholds for cambial and secondary vascular tissue development in stems of hybrid aspen
}

\author{
Peter W. BARLOW ${ }^{a}$, Stephen J. POWERS ${ }^{b}$ \\ a School of Biological Sciences, University of Bristol, Woodland Road, Bristol BS8 1UG, UK \\ $\mathrm{b}$ Biomathematics and Bioinformatics Division, Bawden Building, Rothamsted Research, Harpenden, Hertfordshire AL5 2JQ, UK
}

(Received 19 May 2004; accepted 9 March 2005)

\begin{abstract}
The interaction between environmental conditions and the developing secondary vascular tissue in young stems of hybrid aspen, Populus tremula $\times$ P. tremuloides, was studied with the aid of a differential equation regression model. Two data sets were combined. The first set consisted of the accumulated numbers of cells, such as xylem fibres, vessels, phloem and parenchymatous ray cells, in the radial cell files of stems sampled at intervals over a period of 16 months. Also counted were the numbers of fusiform cambial cells accumulated within the radial files and upon the cambial perimeter (initial cells). The second data set pertained to the external environment, and values were gathered at close time-intervals during the same stem-sampling period. The environmental variables were temperature and illuminance; from the latter, an estimate of day-length was made. These variables were used to construct developmental-time units, values of which were regressed against the accumulated numbers of the various cell types in the secondary vascular tissues. Regression analyses led to estimates not only of rates of cell production but also to the basal threshold values of the environmental parameters, above or below which the various cell productions were initiated or terminated in relation to seasonal conditions. In this way, the critical conditions for the production of each of the various cell types could be identified.
\end{abstract}

cambium / developmental-time units / hybrid aspen / modelling / secondary vascular tissues

Résumé - Détection de seuils de température et de durée du jour pour le développement cambial et la formation de tissus vasculaires dans des troncs de peupliers hybrides. Les interactions entre conditions environnementales et développement des tissus vasculaires secondaires ont été étudiées au cours du développement de jeunes pousses de tremble hybride (Populus tremula $\times$ P. tremuloïdes) à l'aide d'un modèle de régression associé à des équations différentielles. Deux séries de données ont été combinées. La première concernait le nombre de cellules accumulées de différents types - fibres xylémiennes, vaisseaux, cellules de phloème, rayons parenchymateux - dans les files radiales de cellules de tiges échantillonnées à intervalles de temps réguliers sur une période de 16 mois. Étaient aussi pris en compte le nombre de cellules cambiales fusiformes accumulées dans les files radiales et dans le périmètre cambial (cellules initiales). La seconde série de données concernait des variables environnementales externes, dont les valeurs ont été relevées à intervalles de temps rapprochés, tout au long de la période d'échantillonnage des pousses. Les variables environnementales prises en compte sont la température et l'éclairement, donnée à partir de laquelle est estimée la durée du jour. Elles ont été utilisées pour définir des unités de « temps de développement », à partir desquelles se font les régressions contre le nombre de cellules des différents types accumulées dans les tissus vasculaires secondaires. Les analyses de régression permettent d'estimer non seulement le taux de production de cellules, mais aussi les valeurs seuils des paramètres environnementaux au dessus et en dessous desquelles les différents types de productions cellulaires sont initiés ou arrêtés en fonction des conditions saisonnières. De cette manière on a pu identifier les conditions critiques pour la production de chacun de chacun de ces différents types de cellules.

cambium / unité de temps de développement / tremble hybride / modélisation / tissus vasculaires secondaires

\section{INTRODUCTION}

Living organisms are subject to certain "Laws of Development" [22] which, in turn, are governed by the Laws of Chemistry and Physics. Temperature, for example, is an important regulator of biological growth and development, the rates of these processes ultimately being determined by the rates of molecular collisions. The growth of plants is responsive to many abiotic environmental regulators, either alone or in com- bination [26]. Their effects can be quite subtle: for example, cycles of light and dark can combine with cycles of varying temperature to evoke patterns of development not expressed in response to any one of these variable alone [9].

The seasonal cycles of growth and development of temperate tree species are responses to variations in the ambient, abiotic environment $[6,11]$. One cycle is visible in the rhythm of shoot bud burst, flowering, leaf fall and dormancy [27], as well as in the rhythmic activity of the root system [20]. Another

\footnotetext{
* Corresponding author: P.W.Barlow@bristol.ac.uk
} 
cycle is internal and relates to patterns of cellular development, such as the annual increment of the secondary vascular tissues, phloem and xylem. However, growth and development occur only within part of the range of parameter values tolerable for the life of a given species. Above or below some environmentally determined threshold value trees enter a dormant state, and growth activity recommences only when the threshold is crossed once more as the season of the year changes.

In the context of the inter-relationship between the tree and its environment, it is of interest to discover which of the many potentially informative signals originating in the ambient environment actually regulate the developmental cycles mentioned above. Three further questions then arise. The first is: can physical threshold values be established for the perception of environmental signals? Second, what is the impact on growth of each of the environmental parameters once the threshold has been crossed? Third, is it possible to answer the first two questions simply by measuring aspects of tree growth in conjunction with a complementary recording of the environmental variability? Thus, environmental variability itself might be used to extract information about which of the variable parameters are critical for an effect upon growth. A recent model [16] for the statistical analysis of growth of hybrid aspen (Populus tremula $\times$ tremuloides) in relation to a changing environment suggests that it is indeed possible to establish certain of the environmental thresholds as they relate to various aspects of tree development. It was also found possible to assess the relative contribution of these variables to the subsequent rate of growth once the thresholds had been overcome. This paper summarises aspects of this model and presents new results that have been gained from the hybrid aspen material.

\section{MATERIALS AND METHODS}

\subsection{Biological material}

Stem cuttings of hybrid aspen, Populus tremula L. $\times$ P. tremuloides Michx. (clone T89) were potted up and grown in a greenhouse, with no supplementary lighting or heating, located in Long Ashton $\left(51^{\circ} 25^{\prime}\right.$ $\left.\mathrm{N}, 2^{\circ} 40^{\prime} \mathrm{W}\right)$, Bristol, UK. Stem segments were excised $10 \mathrm{~cm}$ above ground level, cut into quarters, and fixed in $2.6 \%$ glutaraldehyde in $0.1 \mathrm{M}$ phosphate buffer, $\mathrm{pH}$ 7.2. After dehydration, the stem sectors were embedded in methacrylate resin. Cross-sections of stems were cut on a microtome, stained in an aqueous mixture of $0.1 \%$ acriflavine, $3 \%$ safranin, $0.1 \%$ auramine and $2 \%$ methylene blue [17], and prepared for light microscopy. Samples were taken at three- or four-week intervals (except during the winter months when the trees were dormant) over a 16 month period from April 1999 until July 2000. Three or four trees were sacrificed on each occasion.

Radial files of cells traversing the cambium, xylem and phloem were identified in the cross-sections. The numbers of cells of various types were counted along the files within the current year's growth increment. Cells in each file of xylem could be further categorised as either fibres, vessels, or latewood. No distinctions between cell types could be made in the developing phloem. The number of parenchyma cells along the radial files of the uniseriate rays were also counted. Estimates were made of the number of cambial cells in a single complete cell row around the cambial circumference: that is, the number of cambial initials from which each radial cell file is descended.

Data pertaining to three abiotic environmental variables surrounding the experimental set of trees were recorded at three-minute inter- vals over the entire growth period and stored for later retrieval and translation into a format [Excel (MicroSoft Corp.) files] compatible with other computer programs [GenStat (Lawes' Agricultural Trust) and SigmaPlot (SPSS Inc.)] for statistical analysis and graphical representation. The recorded variables were ambient temperature $\left({ }^{\circ} \mathrm{C}\right)$ and the illuminance $\left(\mathrm{W} \mathrm{m}^{-2}\right)$ impinging upon the canopy of the trees. From the illuminance data, estimates were automatically made of the third variable, the duration ( $h$ ) of each successive daylight period. This period of daylength was taken as the time during which illuminance was $>2 \mathrm{~W} \mathrm{~m}^{-2}$. Soil moisture and nutrient levels are two additional variables which can affect secondary vascular tissue development [10, 11]. However, in the present experiment, the soil in which the trees were grown was watered to holding capacity every other day, and once a week the trees were fed with $100 \mathrm{mg}$ nitrogen per litre (as dissolved $\mathrm{NH}_{4} \mathrm{NO}_{3}$ ). These two variables were therefore considered as being constant and hence their impacts on development were not assessed further.

\subsection{Units for assessing development - thermal time}

Studies of development that are based on an accumulation of cell numbers are commonly related to the passage of chronological time. Other possible regulatory variables (e.g., temperature) are then usually kept constant so that they can be ignored. The time-scale of observation in such studies is often relatively short, perhaps one or two days. In the case of secondary vascular development in trees, this simplistic approach is not feasible for two reasons: long periods of time (weeks or months, as opposed to days) are required for significant development to be completed and, in an uncontrolled environment, ambient conditions are continually changing throughout the growth period.

Given a suitable analytical (differential equation) model in terms of the rates of change in cell numbers, such as that developed by Powers et al. [16], daily variations of temperature and illuminance, and also the sinusoidal change of day-length throughout the year, can be used to assess the contributions made by these environmental variables to the process of secondary vascular development. This is because these variations provide information for establishing $(a)$ which of them are of critical importance, and $(b)$ the respective threshold values above or below which development proceeds.

A commonly used measure is the "degree-day", a unit first employed by R.-A. de Réaumur. Réaumur postulated (in 1735; cited in [3]) that not only was temperature, in the form of accumulated thermal time, a critical variable in regulating plant development, but that there was also a base temperature below which development did not proceed. This base temperature represents one of the developmental thresholds.

In its simplest form, the sum of day-degrees, $S$, over $n$ days may be expressed as

$$
S=\sum_{d a y=1}^{n}\left(\bar{t}_{d a y}-t_{b}\right)
$$

where $\bar{t}_{d a y}$ is the mean temperature of the entire day for all days on which its value exceeds the base temperature, $t_{b}$. In the present experiments, temperature measurements were sufficiently close together in time so as to form a near-continuous record. The accumulated thermal time (up to time $t$ ) is then the integral given by equation (1):

$$
S=\int^{t}\left(\operatorname{temp}(u)-t_{b}\right) \times H\left(\operatorname{temp}(u)-t_{b}\right) \mathrm{d} u
$$

where $H$ is the Heaviside function which ensures accumulation of thermal time only for temperatures above $t_{b}$, and $u$ is the dummy variable of integration. The rate of development is then estimated in terms of $S$ rather than real time. Both the rate and the base temperature, $t_{b}$, are estimated directly during the course of an iterated search for the best fit between the accumulated cell number and thermal time. 


\subsection{More complex units for development - developmental-time units}

Although temperature has a powerful effect on biological development, it is by no means the only regulating factor. In order to accommodate other environmental variables that can be measured concurrently and are of biological relevance, the thermal time model was modified to employ "developmental-time units". At their most complex, these units include, in addition to temperature, the other two previously mentioned variables, illuminance and daylength, thus giving an accumulation (up to time $t$ ) of temperature-daylength-solar illuminance units, as expressed by equation (2):

$S=\int^{t}\left\{\left(\operatorname{temp}(u)-t_{b}\right) \times H\left(\operatorname{temp}(u)-t_{b}\right) \times\left(\operatorname{dayl}(u)-\operatorname{dayl}_{b}\right)\right.$

$\left.\times H\left(\operatorname{dayl}(u)-\operatorname{dayl}_{b}\right) \times\left(\operatorname{sol}(u)-\operatorname{sol}_{b}\right) \times H\left(\operatorname{sol}(u)-\operatorname{sol}_{b}\right)\right\} \mathrm{d} u$.

Each of the three environmental variables has its own base value, and the Heaviside functions ensure that accumulation stops when any one of them falls below its particular base value. In the present regression modelling of the numbers of cells of different type, all possible combinations of the variables were fitted in a hierarchical way in order to assess their respective strengths in accounting for the total variation of the data. The critical variables were then identified by means of statistical significance tests ( $F$-tests), so that a parsimonious model was the resultant. A full description of the statistical methodology is given in [16].

\section{RESULTS}

A portion of a cross-section of stem of hybrid aspen is illustrated in Figure 1 in which can be seen the major types of cells whose numerical increases were recorded. A general chronology of secondary vascular development for this material is given in Table I from which it is evident that formation of new tissues commences and concludes at specific times of the year. With the aid of the proposed model, however, the temporal development of the various xylem and phloem cell types was examined more precisely. The thresholds that determine the periods of their formation were estimated, the rates of cell productions were followed on a day-by-day basis, and the calendar dates on which productions were maximal were deduced.

When considered in relation to the passage of chronological time, all secondary cell types - xylem, phloem, cambium accumulated in a rhythmic sigmoidal fashion. However, regression analyses were performed upon the accumulated numbers of cells of various types using a developmental-time unit as the dependent variable. Which of the three environmental variables was incorporated into the developmental unit depended upon the ability of the parameter values to improve the fit of the model (i.e., enhance the statistical correlation coefficient of the regression). Where there was a statistically significant $(p<0.05)$ enhancement, the environmental variable was concluded to have made a positive contribution to the production of a given cell type. An example of this approach is shown below in the results for xylem fibres.

\subsection{Xylem fibres}

Temperature, in the form of accumulated thermal time, was used in a first fitting of the data (Fig. 2a). The addition of accu-

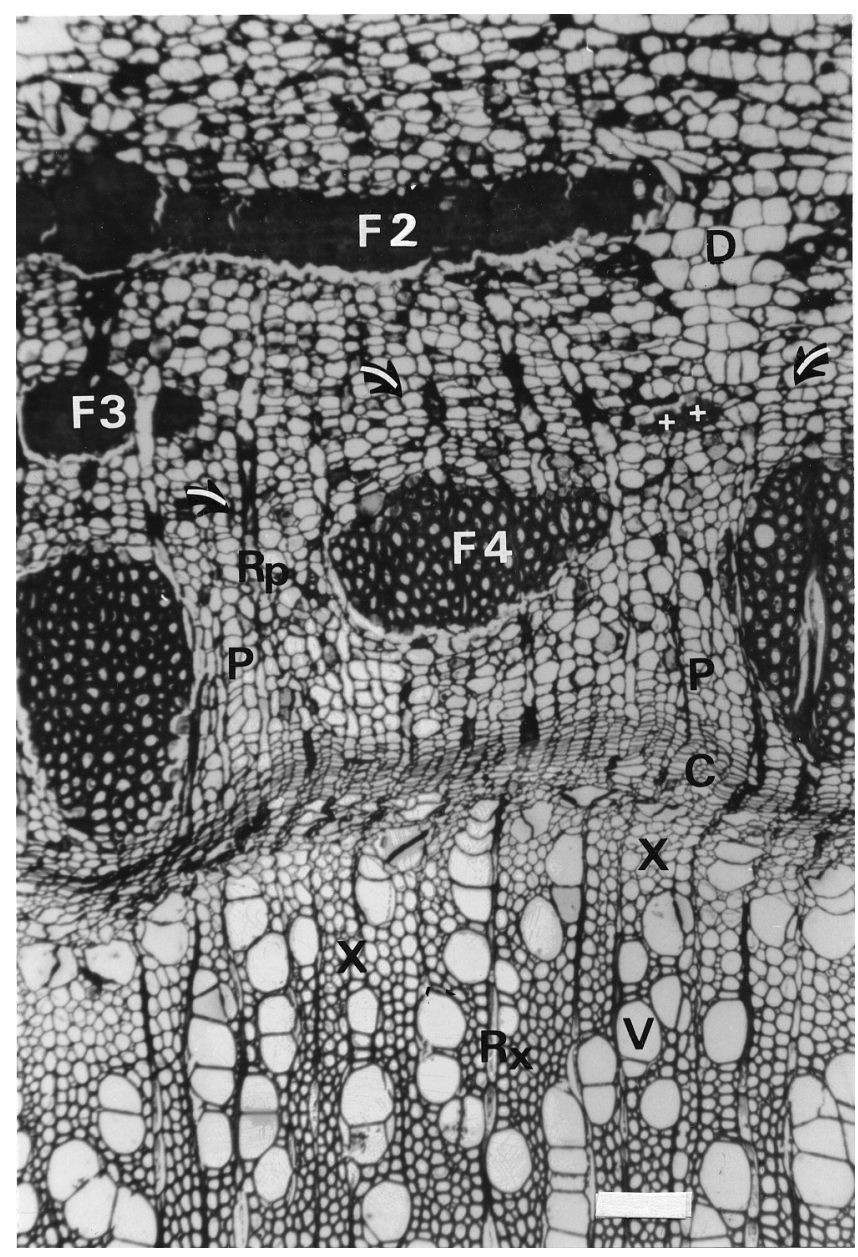

Figure 1. Cross-section of a stem of hybrid aspen sampled on 12 June 2000. C - cambium, D - dilatation ray, F - group of phloem fibres (F2 - F4 indicate the tangential fibre row number), $\mathrm{P}-$ phloem and its various cell types, $\mathrm{R}$ - ray parenchyma in xylem $(\mathrm{Rx})$ and phloem (Rp), V - vessel, X - xylem tissue. Black-and-white arrows point to the boundary between the current year's phloem and that of the previous year (1999). White ++ indicate a small group of phloem fibres within the zone of tangential row F3 but which were interpolated at the time when row F4 was differentiated. Row F1 of phloem is not shown as it lies beyond the upper margin of the photograph in older phloem tissue derived from the primary phloem. Scale bar $=100 \mu \mathrm{m}$.

mulated daylengths significantly $(p<0.05)$ improved the goodness of fit (Fig. 2b), but also resulted in a more complex temperature-day-length developmental-time unit. Both daylength and temperature were therefore deemed critical for the onset of xylem fibre differentiation from fusiform cambial cells. The basal values (thresholds) of the two environmental parameters regulating xylem fibre production are given in Table II.

According to the model, the estimated rate, $\alpha$, of the number of xylem fibre cells formed per cambial cell per developmentaltime unit is given in Table II. Because of the completeness of the record of environmental variables, it is possible to convert the value of $\alpha$ for any particular cell type into the number of cells of that type produced within a radial cell file during any time period. In the present case, the conversion has been made 
Table I. Timetable of internal development within the stems of hybrid aspen (Populus tremula $\times$ P. tremuloides) during the years 1999 and 2000. Stems were one year old at the start of the observation period (April 1999).

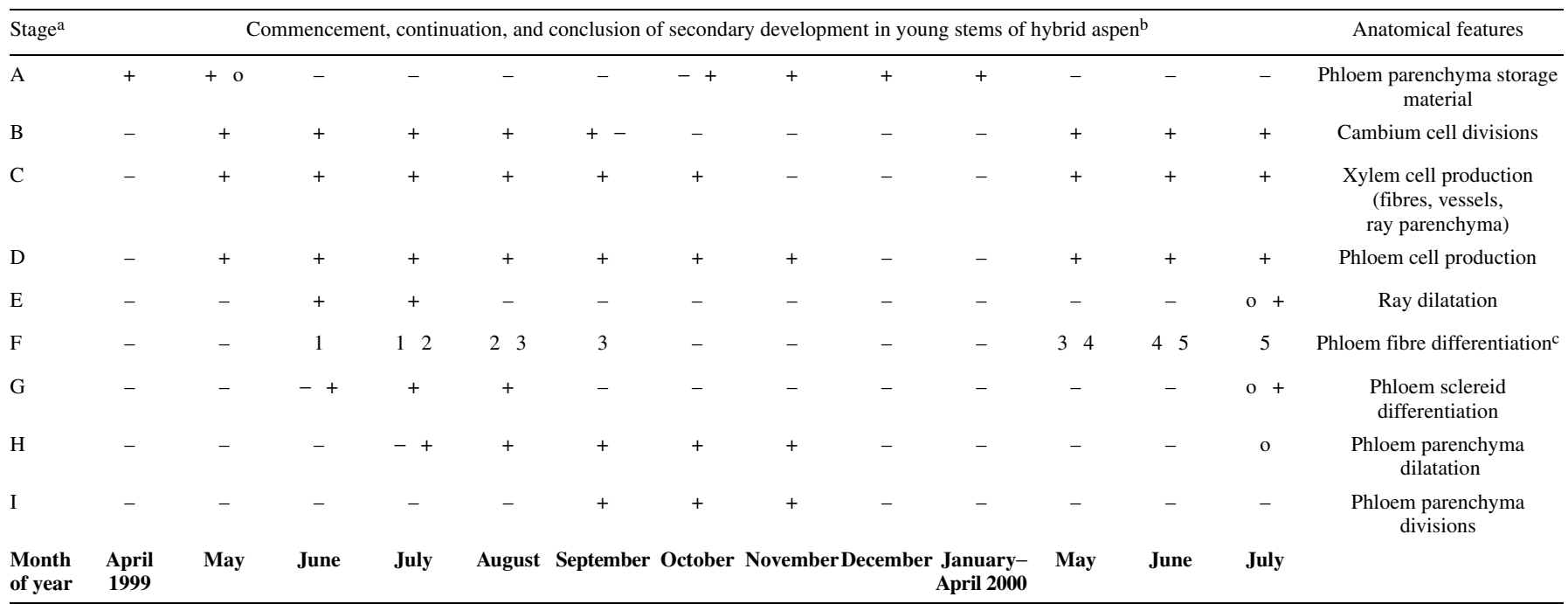

a The features displayed at stages A-I conform to an approximate developmental sequence. These features were evident in stem transections prepared for light microscopy.

b Presence (+) or absence (-), or no record available (o). Two symbols within a box denote that the feature referred to was recorded (or inferred) in both the first and also in the second half of a given month. A single symbol indicates that the feature was constant throughout the indicated period.

${ }^{c}$ The numerals in row F denote the number of rows of groups of phloem fibres seen in cross section. The groups of phloem fibres do not develop in strict centripetal sequence along a radius, but are offset relative to groups in other rows (see Fig. 1). Fibre row number 1 (not shown in Fig. 1) probably lies within primary phloem tissue; rows $2-5$ are in secondary tissue.

Table II. Estimated basal thresholds ( \pm standard errors, s.e.) of environmental variables involved in the production of the various cell types in the secondary vascular system of hybrid aspen stems. $\alpha$ is the elemental rate of cell number increase in relation to the respective developmental-time unit.

\begin{tabular}{|c|c|c|c|c|}
\hline \multirow[b]{2}{*}{ Cell type ${ }^{b}$} & \multicolumn{3}{|c|}{ Estimated basal threshold $( \pm \text { s.e. })^{\mathrm{a}}$} & \multirow[b]{2}{*}{$\alpha \times 10^{4}$} \\
\hline & $\begin{array}{c}\text { Temperature } \\
\left({ }^{\circ} \mathrm{C}\right)\end{array}$ & $\begin{array}{l}\text { Illuminance } \\
\left(\mathrm{W} \mathrm{m}^{-2}\right)\end{array}$ & $\begin{array}{l}\text { Daylength } \\
\text { (h) }\end{array}$ & \\
\hline $\mathrm{F}$ - radial file meristem & $10.69 \pm 0.19$ & $-\mathrm{c}$ & $12.50 \pm 0.06$ & $1.348 \pm 0.05$ \\
\hline $\mathrm{F}$ - initials on cambial perimeter & - & $585.1 \pm 101.0$ & - & $2.79 \pm 1.86$ \\
\hline Xylem fibres & $12.84 \pm 0.17$ & - & $12.37 \pm 0.07$ & $1.49 \pm 0.06$ \\
\hline Phloem & - & - & $13.94 \pm 0.43$ & $34.27 \pm 9.02$ \\
\hline Xylem ray parenchyma & - & - & $14.10 \pm 0.09$ & $63.88 \pm 4.13$ \\
\hline Phloem ray parenchyma & - & - & $9.03 \pm 0.88$ & $3.13 \pm 0.56$ \\
\hline $\mathrm{F}$ and $\mathrm{R}$ - terminal latewood cells & - & - & $12.23 \pm 0.13$ & $0.113 \pm 0.047$ \\
\hline
\end{tabular}

${ }^{a}$ Development proceeds above all the threshold values given, except in the case of the terminal latewood cells, where development proceeds below the values given.

${ }^{\mathrm{b}} \mathrm{F}$ - fusiform cells. Terminal latewood cells derive from this type of cell, and also from ray initials, $\mathrm{R}$, after both types of cells have become dormant. c A blank (-) in any of the boxes of the table indicates that the environmental variable referred to did not make a statistically significant contribution to the regulation of the process of cell production.

for the days when fibre cell production was maximal. The maximal rates of cell formation per file, and the dates on which these occurred, are given in Table III.

\subsection{Phloem and ray cells}

Cumulative cell numbers within the radial files of phloem, and also within the uniseriate files of parenchymatous ray cells which extend from the cambium into both the xylem and phloem tissues, were assessed throughout the sampling period. In each case - for phloem and both types of ray cells - daylength was found to be the determining variable. The threshold values and maximal cellular production rates per cell file are given in Tables II and III.

Data gathered from tangential sections through the cambium of stems sampled in June 1999, and then in November-December 1999, showed that the rays lengthened in the vertical direction. The modal number of cells increased from four to eight 

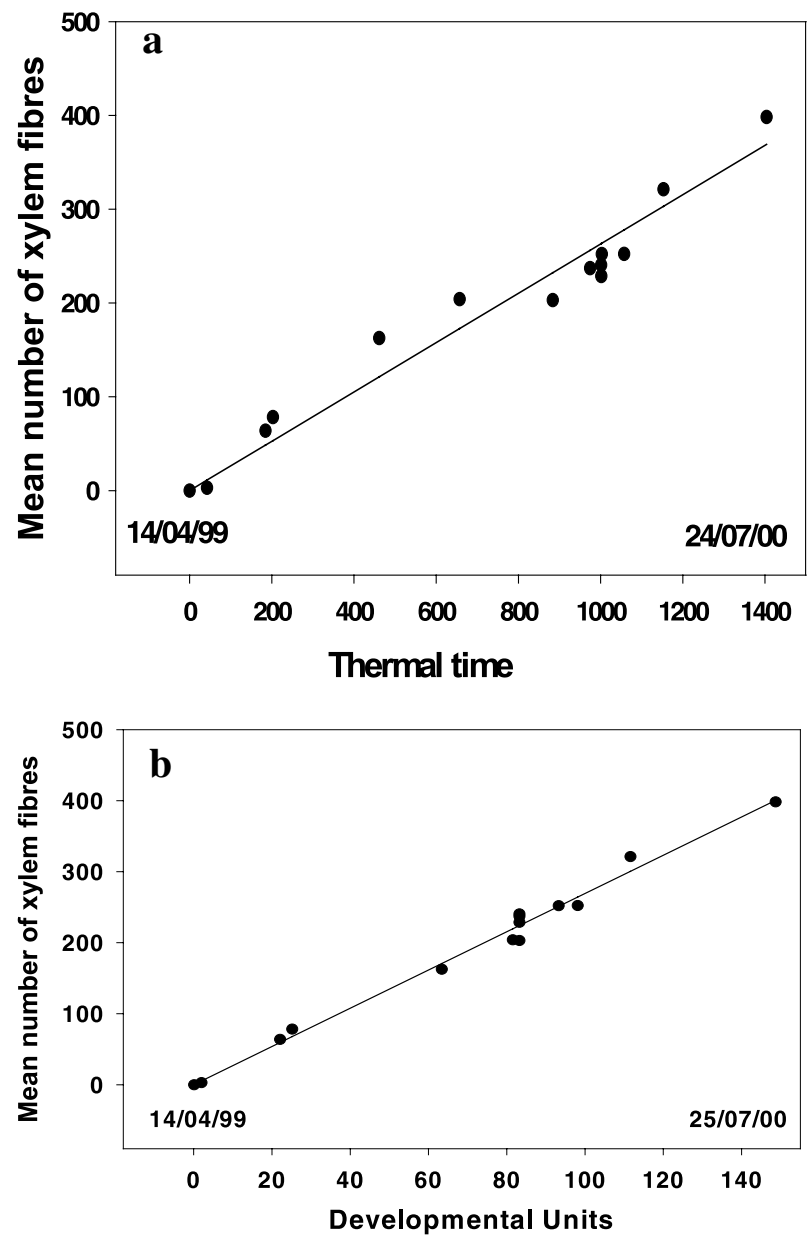

Figure 2. Fitting the accumulated number of secondary xylem fibres per radial file. (a) Fit of fibre numbers versus accumulated daydegrees. There is still evidence of the original sigmoidal pattern of fibre accumulation versus time. (b) Fit of accumulated fibre numbers versus the developmental-time unit of accumulated day-degrees and accumulated daylength values. The sigmoidal pattern of fibre accumulation evident in (a) is absent and the linear fit is now significantly $(p<0.05)$ improved.

cells during this time period. Unfortunately, the data collected from tangential sections did not reveal whether the transverse cell divisions in the rays (those inferred from tangential sections) proceeded simultaneously with the periclinal divisions, the cell productions of which are seen in the cross-sections.

\subsection{Phloem fibres and xylem vessels}

In theory it should be possible to estimate the rate of development of fibres in the more mature zones of the phloem (Fig. 1); that is, the rate at which phloem parenchyma cells convert to fibres. However, the sporadic distribution of the fibres within an annual increment of secondary phloem tissue raises a problem of how best to sample them for analysis. Their distribution suggests that the development of one group of fibres precludes the development of another group in the immediate vicinity. This would account for the staggered arrangement of the groups between neighbouring tangential rows and for the interpolation of new groups in the expanding region between (or within) pre-existing rows (Fig. 1).

The same sampling problem potentially exists for the xylem vessels (Fig. 1). However, their distribution is not so clustered. The vessels arise within a radial cell file from a precursor cell that has newly emerged from the cambium. If this cell is not induced to become a vessel, it becomes a xylem fibre by default [1]. Thresholds for xylem vessel development have been recorded in a previous publication [16].

\subsection{Fusiform cambial cells}

Numbers of fusiform cambial cells, as recorded from crosssections of sectors of stems, were estimated in the two directions. In the first case, fusiform cells were counted along the radial files in the xylem portion of the cambium (i.e., to the inside of the cambial initials). In the second case, the total number of fusiform initial cells (ray initial cells were ignored) was estimated by extrapolation from cell counts along an arc of the cambial perimeter. The number of fusiform cells in the radial cell files is related to the number of periclinal divisions in both the fusiform initials and their meristematic derivatives. Their cellular kinetics are described elsewhere $[2,16]$ but, for completeness, their thresholds and elemental rates of cell production $(\alpha)$ towards the xylem are given in Tables II and III.

The estimated number of fusiform cells on the cambial perimeter showed a regular stepwise increase from one season to the next. This increase is due to the radial cell divisions within these cells. The threshold for their development, and their elemental $(\alpha)$ and maximal rates of production, are given in Tables II and III.

Illuminance was statistically the best regulator for the increase in cell numbers on the cambial perimeter - that is, the number of initial cells produced by radial cell divisions. By contrast, temperature and daylength together were shown statistically to be the best regulators of cell numbers within the radial cell files of the vascular cambium [16]. In both cases, the models, in terms of the respective developmental units derived using the corresponding estimated basal values, accounted for more than $95 \%$ of the variation in the sets of data.

The number of fusiform cells in the radial files on the xylem side of the cambium varied with the time of year, increasing to a maximum of about 10-11 cells in early summer, and then decreasing as autumn approached. These periodic variations are the consequence of the balance maintained between the rate of periclinal cambial cell divisions and the rate of differentiation of the cells as xylem fibres and parenchyma. In early summer, the rate of centripetal cell productions from the cambium outpaces the opposing rate of centrifugal differentiation, whereas in late summer, the number of dividing cells in the radial files decreases because the rate of differentiation outpaces the rate of cell production. More detailed analyses (not shown here) revealed that during the period when the cambium was decreasing radially, its circumference was still increasing. This may be a consequence of distinct basal thresholds for the two classes of cell division, periclinal and radial. When the basal thresholds for fusiform cell divisions are crossed, the cambium becomes effectively dormant. 
Table III. Conversion of the elemental rate, $\alpha$, which refers to the number of new cells produced per cell per developmental-time unit, into either the maximum number of cells added per radial cell file per day or the maximum number of cells produced per cell per day. The dates in the last column are when conditions for maximum rates of cell production in the hybrid aspen trees were achieved in the years 1999 and 2000.

\begin{tabular}{|c|c|c|c|c|}
\hline Cell type & Developmental-time unit & $\alpha \times 10^{4}$ & $\begin{array}{l}\text { Cells per cell per day }(*) \text { or cells } \\
\text { added per file per day }\left(^{\dagger}\right)^{\mathrm{a}}\end{array}$ & Date of maximal cell addition \\
\hline \multirow[t]{2}{*}{$\begin{array}{l}\text { Fusiform cambial cells (periclinal } \\
\text { divisions towards the xylem) }\end{array}$} & Temperature and day-length & 1.35 & $0.72^{*}$ & 9-07-1999 \\
\hline & & & $0.85^{*}$ & $19-06-2000$ \\
\hline $\begin{array}{l}\text { Fusiform cambial initials (radial } \\
\text { divisions) }\end{array}$ & Illuminance & 2.79 & $\begin{array}{c}0.12^{*} \\
\text { on all occasions }\end{array}$ & $\begin{array}{c}13 \text { dates between } \\
\text { 2-06-1999 and 4-08-1999, } \\
\text { and between 24-04-2000 } \\
\text { and 21-07-2000 }\end{array}$ \\
\hline \multirow[t]{2}{*}{ Xylem fibre } & Temperature and Day-length & 1.49 & $5.92^{\dagger}$ & \\
\hline & & & $7.12^{\dagger}$ & $19-06-2000$ \\
\hline \multirow[t]{2}{*}{ Xylem ray parenchyma } & Day-length & 63 & $1.11^{\dagger}$ & 17-06-1999 \\
\hline & & 00.00 & $1.13^{\dagger}$ & $23-06-2000$ \\
\hline \multirow[t]{2}{*}{ Phloem } & Day-length & & $0.63 * \dagger$ & 17-06-1999 \\
\hline & & 34.27 & $0.64 * \dagger$ & 23-06-2000 \\
\hline Phloem ray parenchyma & Day-length & 3.13 & $0.15^{\dagger}$ & $\begin{array}{l}\text { 17-06-1999 } \\
\text { and } \\
23-06-2000\end{array}$ \\
\hline \multirow[t]{2}{*}{ Terminal latewood cells } & Day-length & 0.11 & & \\
\hline & & & $0.011^{*}$ & 4-01-2000 \\
\hline
\end{tabular}

${ }^{\mathrm{a}}$ In the case of fusiform initial cells, the rate of cell production towards the xylem, the phloem, and within the cambial perimeter, have all to be considered. Hence, the overall maximal rate for the tri-directional cell production from the fusiform initials in the year 2000 is $0.12+0.85+0.64=1.61$ cells per cell per day.

\subsection{Cambial dormancy and terminal latewood cells}

Approximately three dormant cambial cells, as judged by the differential staining of their walls, were seen in each radial file to the inside of the former initials (i.e., within the domain of the xylem). The non-enlargement of one, or occasionally two, of these cells during the spring of the following year helped to identify a double band of flattened, parenchymatous terminal latewood cells. These cells formed the boundary between one completed annual growth increment and the one that was currently developing.

The statistical modelling revealed that the onset of development of terminal latewood cells was insensitive to temperature but was regulated by daylengths $<12.23 \mathrm{~h}$ (or by corresponding dark periods $>11.77 \mathrm{~h}$ ) (Tab. II). Such day-/night-time values occurred between 25-09-1999 and 19-03-2000. Microscopic observations of the transected stems showed that during this period the percentage of radial files containing a terminal latewood cell increased progressively (data not shown) until each file contained at least one such cell. On 20-09-99, 31\% of secondary xylem radial files had one recognisable terminal latewood cell in the zone of the former cambium; on 01-11-99 and 13-12-99, the respective values were $66 \%$ and $83 \%$. A complete ring (97-100\% of files with latewood cells) was evident in samples taken after February in the following year, around the time when nights were beginning to shorten. The threshold for the development of this cell type was crossed in mid-March, at which time latewood cell differentiation was complete.

The slow conversion of dormant cambial cells into a ring of terminal latewood cells is indicated by the low value of $\alpha$ (Tab. II). This rate applies only when the night period is $>11.77 \mathrm{~h}$. The dates on which maximal rates of terminal cell formation occurred are shown in Table III.

\subsection{Predicting vascular development}

Because of the completeness of the environmental data, it was possible to calculate average parameter values for chosen time periods. Accordingly, averages of temperature and daylength per successive 28-day periods provided a set of values across a year's growth period. These average values define the positions of the nodes of the polygon shown in Figure 4. The polygon itself shows the relationship between temperature and day-length during the one-year period. These two environmental variables are those which influence all the analysed secondary tissue developments, except for the cambial initials (see Tab. II). Tracing around the polygon, there are 14 threshold steps that govern the various types of cell productions. These are superimposed upon Figure 4, thus providing a visual summary of the developmental pattern of the secondary tissue. Generally, the chronological pattern of tissue development - for example, at what times of year the vascular cambium is active, 
in which months phloem is being produced, and so on - conforms to the pattern summarised in Table I.

\section{DISCUSSION}

It is customary to assess rates of growth and development in terms of a time-based increase in cell number. This is convenient in circumstances where environmental conditions are unchanging. Hence, there would then be only two variables of importance, cell number and time. In describing secondary vascular development with the aid of the present model, where composite developmental-time units are employed, the question arises as to whether all the variables are necessary. All combinations of the environmental variables were fitted, and those considered critical were identified by means of statistical significance. The fit for the secondary xylem fibre accumulation, for example, was improved when day-length was included as a variable (see Figs. $2 \mathrm{a}$ and $2 \mathrm{~b}$ ). The developmental-time unit appropriate for xylem fibre production is therefore a temperature-day-length unit (Tab. II). In this circumstance, the basal temperature, $t_{b}$, was estimated as $12.84{ }^{\circ} \mathrm{C} \pm 0.17$, a value higher than this $\left(t_{b}=15.19^{\circ} \mathrm{C}\right)$ was obtained when xylem fibre development was considered in terms of degree-days only. The inclusion of the third variable, illuminance, to the developmental-time unit did not improve the goodness of fit.

Some caution is necessary before regarding any variable as non-critical. Even if its inclusion does not result in a statistically significant improvement of the relationship between accumulated cell number and the developmental-time unit, it could still be a facilitating factor. For example, solar illuminance is clearly the source of energy for the production of carbohydrate without which development would not be possible [6], and Ford et al. [5] found evidence that accelerated bursts of tracheid production in stems of Picea sitchensis (up to 12 cells per file per day) might be related to especially high levels of solar radiation. However, in this last-mentioned study [5] wood samples were taken every $12 \mathrm{~h}$, and such close sampling times may reveal features that escape notice when sampling is less frequent. In the present case of hybrid aspen, the apparent non-dependence of xylem fibre production upon illuminance, as shown through modelling, may mean only that this environmental variable was non-limiting for the development of this particular cell type.

Another, but different, set of environmental dependencies is displayed by the developing radial files of secondary phloem (Tab. II). Here, the best fit for cell number increase was found when a day-length developmental-time unit was used. The additional contribution from temperature to this model was not statistically significant. Again, it should not be assumed that temperature had no effect on the system, but only that daylength had a more critical effect in its ability to account for variablity in the data.

One assumption made with respect to the perception of temperature and, indeed, to the other environmental variables also, is that changes in temperature were registered instantly by the developing system. In the general case, this is unlikely because of the insulating property of the bark $[19,25]$. The bark of the experimental group of hybrid aspen trees was thin, however, and it was supposed that, even if temperature tracking by the cambium and xylem fibres (whose cell numbers show a tem- perature dependency) were not exactly coincident with ambient conditions, the systems would be in reasonable conformity with the assumptions of the model. A study of bark, including that of Populus species [15], did, in fact, show that the external temperature of the bark could be quite similar to that recorded simultaneously in the cambium. The results of a sensitivity analysis [16] indicated that simultaneous tracking of the external temperature by the internal tissues is not a critical requirement of the model. Nevertheless, if the thermal conductivity of the overlying tissues were known, it might be possible to estimate any lag in temperature perception.

The quite different day-length thresholds for phloem and xylem ray parenchyma production (Tab. II) require comment. The phloem rays undergo dilatation growth late in the year (Tab. I). The lower threshold for phloem ray cell production may be indicative of conditions which permit periclinal divisions in locations other than the cambial zone. It is possible, therefore, that the new cells accumulated in the dilatation zone, and did so under the influence of a more permissive basal temperature threshold. However, to show exactly where along the ray these presumed periclinal divisions were occurring would require careful measurement of radial cell lengths. The secondary division zone might then be found to correspond to a region of ray, probably close to the dilatation zone, where cell lengths show a periodic decrease.

Unlike the situation in the radial files of cambial fusiform cells where the number of dividing cells can fluctuate, radial files of cambial ray cells show no such expansion or contraction of their cell division zone. There always seems to be just one dividing ray file initial cell per radial file of ray parenchyma. Similar thresholds probably apply to the periclinal divisions which lead to new cells being introduced into the xylem and phloem regions of the rays because the productions into both zones seem to originate from a common ray initial cell.

Unfortunately, little is known of the vertical growth of the rays. To study this requires the preparation of tangential stem sections [1]. However, there does seem to be some rhythm in this vertical aspect of ray growth as evidenced by the change in ray cell numbers in the vertical plane.

The basal thresholds established for a given developmental process were assumed to operate in two modes, as both an "on" switch and an "off" switch. That is, the same parameter value not only permitted a process to commence when the threshold parameter value was exceeded, but also terminated that process when the value fell below the threshold at, say, the end of the growing season. One might object to this assumption on the grounds that a dormant tree does not share the same physiological state as one that is actively growing and, hence, the threshold value which permits the transition from cambial dormancy to activity does not need to be the same as that which renders the active state dormant once more. From the present modelling, there is no way of telling whether this argument has any merit. The estimated basal threshold values stated in Table II are those which statistically satisfy both the activation and the deactivation of a cell production process.

The two states of the cambium (active and inactive or dormant) may also be regulated by means of a biotic variable to which is linked a critical abiotic variable (such as one of the three environmental factors studied). An example is the linkage 


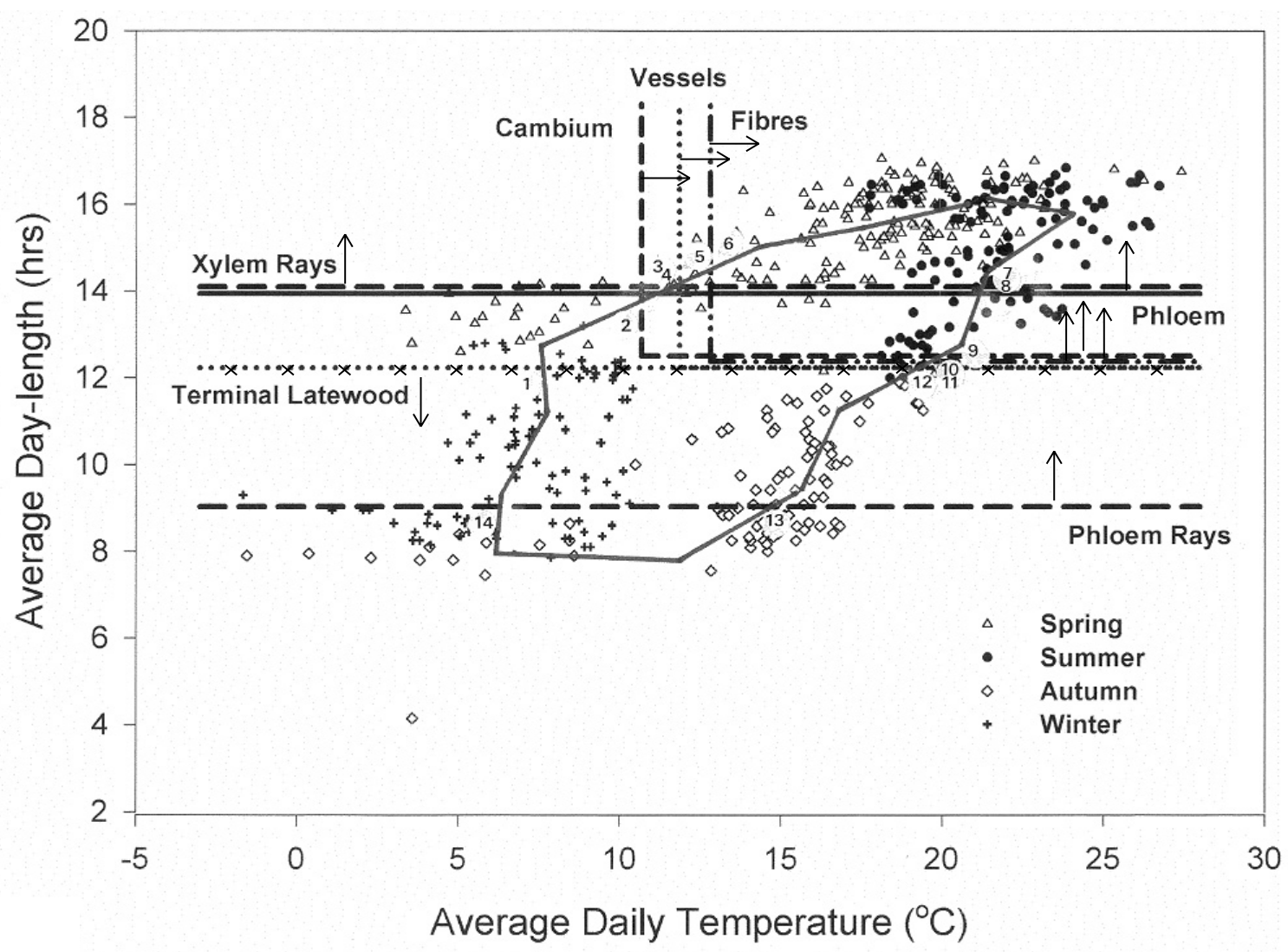

Figure 3. Relationship of temperature and day-length during the tree-sampling period of 1999-2000. Each point represents the mean temperature and day-length value for one day during each of the four seasons, spring, summer, autumn and winter. The nodes of the polygon inscribed in the graph represent the mean values for successive 28-day periods, starting from day 1 on 14-04-1999. The vertical and horizontal lines in the graph represent the threshold values for the accumulation of the indicated secondary vascular cell types. For periclinal divisions in the cambium, and for the increase in the number of xylem fibres and vessels, accumulation is initiated to the right and above the respective vertical and horizontal lines (indicated by arrows). For xylem and phloem ray cells, and for phloem, accumulation is initiated above their respective horizontal lines (arrowed). For terminal latewood, accumulation is initiated below the horizontal line (arrowed). Fourteen transitions are marked (1-14). Accumulation of a given cell type can occur only when the correct transition(s) has been passed.

between day-length and auxin [21], and between day-length and gibberellin metabolism [4]. Auxin provides the permissive endogenous physiological environment for cambial cell divisions [23, 24]. Accordingly, a certain auxin status is a pre-condition for the cambial system to become responsive to environmental factors which further regulate its activity. Sources of auxin are the young leaves [14] and, perhaps, the expanding internodes of young stems. Thus, a certain number of young leaves and internodes may need to have been developed in order for the auxin-dependent pre-condition for temperature- or day-length-regulated cambial activation to be fulfilled. By the same token, the reversion to dormancy may be assisted by a curtailment of the production of young leaves.

It is likely that additional parameters, such as soil moisture and nutritional levels, would also have been found to be critical $[7,11]$ had they been allowed to make a variable impact on tissue development. In the present experiments, daily watering preserved an approximate constancy of soil moisture. A decrease in soil moisture can lead to the appearance of "false" growth rings [7] composed of a latewood-type of parenchymatous cell, a cell type whose differentiation is possibly mediated by both a temporary increase in the level of abscisic acid and a decrease in the level of auxin required to maintain cambial activity $[12,13]$. With regard to nutrients, experiments with the same clone of hybrid aspen have shown that the number of cambial cells undergoing periclinal division is affected by the nitrogen $\left(\right.$ as $\left.\mathrm{NH}_{4}^{+}\right)$status of the soil [8]. Low nitrogen, for example, was found to diminish the rate of production of xylem fibres. However, in the present case, the soil nitrogen levels were maintained at a constant level.

Cytological changes within the radial cell files could also be studied by the present model. For example, secondary xylem fibres change from an immature state in which their cytoplasmic contents are present, to a mature state where the cells have enlarged, their contents have autolysed, and the cell walls have thickened $[10,17]$. Phloem fibres could be particularly interesting to study since they occur with predictable spacing patterns, develop at particular times of the year (Tab. I), and then 
undergo further maturation into fibre sclereids within the bark [18]. Detailed observation could thus reveal the thresholds attending these more subtle, microscopic aspects of development.

The day-length and temperature thresholds for the development of the various secondary vascular cell types mentioned in Table II were combined in a graph showing the relationship between these two environmental variables. One way to visualise the developmental sequence is to trace clockwise around the polygon in Figure 3 that relates average monthly daylengths and temperatures. Wherever the trace cuts a threshold line, then some developmental event either commences or ceases. Such events show the expected temporal sequence in accordance with the estimated environmental thresholds provided by the modelling. In the present case, cambial and phloem cell production slightly preceded xylem fibre formation and, likewise, cambial activity ceased before differentiation of the cells produced by periclinal divisions had been completed. This intuitively conforms to biological reasoning about the process of initiation and cessation of cell production in the cambial system.

Lastly, visible phenological events relevant to secondary vascular development should not be ignored. In the present material, for example, the onset of cambial activity in springtime was associated with the resumed growth of shoot buds and the unfurling of their leaves (our unpublished data; see also [14, 21]). Conversely, the cessation of cambial development might be coincident with senescence of these leaves and the entry of the shoot buds into dormancy. The thresholds for these whole plant events could therefore bear some relationship to the more microscopic, histological aspects of development whose thresholds have been indicated in Figure 3.

Acknowledgements: The trees used in this experiment were initially raised by Professor B. Sundberg (Swedish Agricultural University, Umeå, Sweden) and then maintained at the former Long Ashton Research Station, University of Bristol. Much of the sectioned material, and some of the cell counts, were prepared in the Institut für Forstbotanik und Baumphysiologie, Albert-Ludwigs Universität, Freiburg, Germany, by Dr L. Puech and Miss M. Wittenzellner, under the guidance of Professor Dr S. Fink. Part of the work was supported by a grant from the Commission of the European Communities.

\section{REFERENCES}

[1] Barlow P.W., From cambium to early cell differentiation within the secondary vascular system, in: Holbrook N.M., Zwieniecki M. (Eds.), Vascular Transport in Plants, Elsevier/Academic Press, Amsterdam, 2005, pp. 279-306.

[2] Barlow P.W., Brain P., Powers S.J., Estimation of directional division frequencies in vascular cambium and in marginal meristematic cells of plants, Cell Prolif. 35 (2002) 49-65.

[3] Bonhomme R., Bases and limits to using “degree.day" units, Eur. J. Agron. 13 (2000) 1-10.

[4] Eriksson M.E., Moritz T., Daylength and spatial expression of a gibberellin 20-oxidase isolated from hybrid aspen (Populus tremula L. $\times$ P. tremuloides Michx.), Planta 214 (2002) 920-930.

[5] Ford E.D., Robards A.W., Piney M.D., Influence of environmental factors on cell production and differentiation in the early wood of Picea sitchensis, Ann. Bot. (1978) 683-692.

[6] Fritts H.C., Shashkin A., Downes G.M., A simulation model of conifer ring growth and cell structure, in: Wimmer R., Vetter R.E.
(Eds.), Tree-Ring Analysis, CABI International, Wallingford, 1999, pp. 3-32.

[7] Glock W.S., Agerter S.R., Rainfall and tree growth, in: Kozlowski T.T. (Ed.), Tree Growth, Ronald Press, New York, 1962, pp. 23-56.

[8] Hellgren J.M., Puech L., Barlow P., Fink S., Mellerowicz E.J., Sundberg B., Auxin and cambial growth rate in poplar, Sylvestria 268 (2003) 95-105.

[9] Hellmers H., Distribution of growth in tree seedling stems as affected by temperature and light, in: Zimmermann M.H. (Ed.), The Formation of Wood in Forest Trees, Academic Press, New York, 1964, pp. 533-547.

[10] Horacek P., Slezingerova J., Gandelova L., Effects of environment on the xylogenesis of Norway spruce (Picea abies [L.] Karst.), in: Wimmer R., Vetter R.E. (Eds.), Tree-Ring Analysis, CABI International, Wallingford, 1999, pp. 33-53.

[11] Kozlowski T.T., Pallardy S.G., Growth Control in Woody Plants, Academic Press, San Diego, 1997.

[12] Lachaud S., Participation of auxin and abscisic acid in the regulation of seasonal variations in cambial activity and xylogenesis, Trees 3 (1989) 125-137.

[13] Little C.H.A., Wareing P.F., Control of cambial activity and dormancy in Picea sitchensis by indol-3-ylacetic and abscisic acids, Can. J. Bot. 59 (1981) 1480-1493.

[14] Ljung K., Bhalerao R., Sandberg G., Sites and homeostatic control of auxin biosynthesis in Arabidopsis during vegetative growth, Plant J. 28 (2001) 465-474.

[15] Nicolai V., The bark of trees: thermal properties, microclimate and fauna, Oecologia 69 (1986) 148-160.

[16] Powers S.J., Brain P., Barlow P.W., First-order differential equation models with estimable parameters as functions of environmental variables and their application to a study of vascular development in young hybrid aspen stems, J. Theor. Biol. 222 (2003) 219232.

[17] Puech L., Türk S., Hodson J., Fink S., Wood formation in hybrid aspen (Populus tremula L. $\times$ Populus tremuloides Michx.) grown under different nitrogen regimes, in: Savidge R., Barnett J., Napier R. (Eds.), Cell and Molecular Biology of Wood Formation, BIOS Scientific Publishers, Oxford, 2000, pp. 141-153.

[18] Rees W., Shiue C.-J., The structure and development of the bark of quaking aspen, Proc. Minn. Acad. Sci. 25-26 (1957-58) 113-125.

[19] Reifsnyder W.E., Herrington L.P., Spalt K.W., Thermophysical properties of bark of shortleaf, longleaf and red pine, Yale University School of Forestry, Bulletin No. 70, 1967, pp. 1-40.

[20] Riedacker A., Rythmes de croissance et de régénération des racines des végétaux ligneux, Ann. Sci. For. 33 (1976) 109-138.

[21] Schrader J., Baba K., May S.T., Palme K., Bennett M., Bhalerao R.P., Sandberg G., Polar auxin transport in the wood-forming tissues of hybrid aspen is under simultaneous control of developmental and environmental signals, Proc. Natl. Acad. Sci. 100 (2003) 10096-10101.

[22] Souèges R., Les Lois de Développement, Actualités Scientifiques et Industrielles $\mathrm{N}^{\circ}$ 521, Hermann, Paris, 1937.

[23] Uggla C., Moritz M., Sandberg G., Sundberg B., Auxin as a positional signal in pattern formation in plants, Proc. Natl. Acad. Sci. USA 93 (1996) 9282-9286.

[24] Uggla C., Mellerowicz E.J., Sundberg B., Indole-3-acetic acid controls cambial growth in Scots pine by positional signaling, Plant Physiol. 117 (1998) 113-121.

[25] Vines R.C., Heat transfer through bark, and the resistance of trees to fire, Aust. J. Bot. 16 (1968) 499-514.

[26] Went F.W., Sheps L.O., Environmental factors in regulation of growth and development: ecological factors, in: Steward F.C. (Ed.), Plant Physiology. A Treatise. Vol. VA: Analysis of Growth: Behavior of Plants and their Organs, Academic Press, New York, 1969, pp. 299-406.

[27] Zimmermann M.H., Brown C.L., Trees. Structure and Function, Springer, Berlin, 1971. 